\title{
The Impact of Large-scale Asset Purchases on the S\&P 500 index, Long-term Interest Rates and Unemployment
}

Anastasios G. Malliaris

Loyola University Chicago, tmallia@luc.edu

Ramaprasad Bhar

The University of New South Wales

Follow this and additional works at: https://ecommons.luc.edu/business_facpubs

Part of the Business Commons

\section{Author Manuscript}

This is a pre-publication author manuscript of the final, published article.

\section{Recommended Citation}

Malliaris, Anastasios G. and Bhar, Ramaprasad. The Impact of Large-scale Asset Purchases on the S\&P 500 index, Long-term Interest Rates and Unemployment. Applied Economics, 47, 55: 6010-6018, 2015. Retrieved from Loyola eCommons, School of Business: Faculty Publications and Other Works, http://dx.doi.org/10.1080/00036846.2015.1061646

This Article is brought to you for free and open access by the Faculty Publications and Other Works by Department at Loyola eCommons. It has been accepted for inclusion in School of Business: Faculty Publications and Other Works by an authorized administrator of Loyola eCommons. For more information, please contact ecommons@luc.edu.

\section{(c) $($ () $\ominus$}

This work is licensed under a Creative Commons Attribution-Noncommercial-No Derivative Works 3.0 License. (C) Taylor \& Francis 2015 


\title{
THE IMPACT OF LARGE-SCALE ASSET PURCHASES ON THE S\&P 500 INDEX, LONG-TERM INTEREST RATES AND UNEMPLOYMENT \\ RAMAPRASAD BHAR \\ UNSW Business \\ THE UNIVERSITY OF NEW SOUTH WALES \\ UNSW Sydney 2052, AUSTRALIA \\ R.Bhar@unsw.edu.au
}

\author{
A.G. MALLIARIS \\ LOYOLA UNIVERSITY CHICAGO \\ 1 EAST PEARSON STREET \\ CHICAGO, ILLINOIS 60611 \\ tmallia@luc.edu \\ MARY MALLIARIS \\ LOYOLA UNIVERSITY CHICAGO \\ 1 EAST PEARSON STREET \\ CHICAGO, ILLINOIS 60611 \\ mmallia@luc.edu
}

\begin{abstract}
:
After the bankruptcy of Lehman Brothers in September of 2008 and the financial panic that ensued, the Federal Reserve moved rapidly to reduce the federal funds rate to $.25 \%$. It was quickly judged that additional measures were needed to stabilize the U.S. economy. Beginning in December 2008, the Federal Reserve Bank initiated three rounds of unconventional monetary policies known as Quantitative Easing. These policies were intended to reduce long-term interest rates when the short term federal funds rates had reached the zero lower bound and could not become negative. It was argued that the lowering of longer-term interest rates would help the stock market and thus the wealth of consumers. This paper carefully investigates three hypotheses: QE impacting long-term interest rates, QE impacting the stock market and QE impacting unemployment using a Markov regime switching methodology. We conclude that quantitative easing has contributed significantly to increases in the stock market but less significantly to long-term interest rate and unemployment.
\end{abstract}

Key words: Quantitative Easing, Stock Market, S\&P 500 Index, 10 Year Notes, Unemployment. JEL Classification: C10; C51; C58; E52; E58.

Date of this draft: June 8, 2015 


\section{THE IMPACT OF LARGE-SCALE ASSET PURCHASES ON THE S\&P 500 INDEX, LONG-TERM INTEREST RATES AND UNEMPLOYMENT}

\section{Introduction}

Before the Global Financial Crisis, monetary policy in the U.S. typically consisted of the Federal Open Market Committee (FOMC) setting a target for the federal funds rate which is the overnight interest rate at which banks lend to one another. The target for the fed funds rate was determined by some version of the Taylor rule that expressed the target fed funds rate as the sum of certain terms expressing values of the long-run real interest rate, the target rate of inflation, the deviation of actual real output from potential real output and the deviation of actual inflation from the targeted inflation, with the last two terms receiving certain weights adding to one. The Fed did not use the Taylor rule mechanically; it evaluated numerous economic developments that surrounded the particular economic conditions prevailing at that time and followed a risk management approach in selecting the targeted fed funds rate. This meant that if there were certain risks with low probability but with potentially very high costs, such as the Y2K problem, the FOMC was prepared to lower the fed funds relative to the Taylor rule number to counter the risks of that period.

The Lehman bankruptcy in mid-September 2008 and the severe financial panic that was triggered from this unexpected development induced the Fed to rapidly reduce the fed funds rate to $.25 \%$ that is essentially zero. A Taylor rule mechanical calculation during the last quarter of 2008 would have produced a negative fed funds rate but since the Fed was constrained by the zero as its lower bound, it became quickly apparent that unconventional new tools were necessary to help the U.S. economy stabilize. The large-scale asset purchases (LSAP) or Quantitative Easing (QE) as they were called, was such a tool. QE consists of the Federal Reserve purchasing U.S. Treasury securities and agency mortgage-backed securities (MBS) with the aim of driving down longer-term interest rates, thereby stimulating economic activity. 
It is the purpose of this paper to carefully investigate the impact of quantitative easing on the stock market, the 10-Year Treasury Note and Unemployment. We first give a brief overview of $\mathrm{QE}$, in section 2 and then in section 3 discuss selectively the literature that evaluates the performance of QE. After this introductory analysis we formulate our hypotheses and describe the data used in section 4. The methodology used and the results are presented and discussed in section 5 and conclusions are summarized in section 6.

\section{The Evolution of $Q E$}

The series of 3 QE between the Fall of 2008 and the termination of the third during the Fall of 2014 was, obviously, not planned in advance. Each QE had its own characteristics. The first one signaled the Fed's strong determination to contain the Great Recession and, it may be argued, contributed to the termination of the recession in June 2009. The second and third QE were initiated because of subpar recovery with persistent high unemployment and low inflation. In all three QE strategies, the Fed reasoned that such a reduction in longer-term rates would allow firms to save on their debt refinancing and other things being equal to achieve higher earnings and profits thus helping their stocks and restoring the wealth of households that held such stocks as a driver of stabilizing the real economy.

QE1 was announced by the FOMC on November 25, 2008. The plans were for the Fed to purchase $\$ 600$ billion on Mortgage Backed Securities (MBS) and Agency Debt. The plan was officially implemented on December 15, 2008. It was extended on March 18, 2009 when the FOMC announced the purchase of an additional $\$ 750$ billion in MBS and $\$ 300$ billion of Treasuries. The plan was concluded by December 2009.

QE2 was announced by Chairman Bernanke in his Jackson Hole speech on August 27, 2010 and officially implemented in early November 2010. QE@ consisted of $\$ 600$ billion of Treasury Bonds purchases. On September 21, 2011, the FOMC announced plans for purchasing $\$ 400$ billion in longer-dated Treasuries by selling shorter-dated ones. This was known as Operations Twist. This Program was extended by an additional \$267 billion on June 20, 2012.

QE3 was announced by the FOMC on September 2012. It did not specify the total amount but indicated monthly purchases of $\$ 40$ billion in MBS. This monthly amount was increased by another $\$ 45$ billion of purchases of Treasuries on December 12, 2012. This monthly 
amount of $\$ 85$ billion of purchases of MBS and Treasuries continued for all of 2013 and was tapered gradually over 10 months prior to its termination on October 29, 2014.

As a result of these QE strategies the balance sheet of the Fed has expanded from about 1 trillion of assets prior to the crisis to over $\$ 4$ trillion during the third quarter of 2014 . The critical question is this: what have these three massive Quantitative Easings have accomplished? There is a general and a particular response. The general response claims that when the Fed reached its zero lower bound, it became obvious that the stabilization of the US economy required additional monetary stimulus, because economic growth was very slow and there was no risk of inflation. The gradual return to moderate economic growth of the US real economy since the end of the Great Recession in June of 2009 is partial evidence of the overall effectiveness of the 3 QEs. The particulars of these strategies address the channels of monetary transmission: if QE reduces longer term interest rates, then consumers may pay less for their debt obligations and thus have more money for consumption; simultaneously, longer term interests reduce the debt obligations of corporations and private firms, thus increasing their profits and contributing to higher asset valuations. In turn, such higher asset valuations encourage corporate business investments and increases in employment. These ideas will guide the formulation of our hypotheses.

\section{Review of the Literature}

Numerous studies have investigated the impact of large scale securities purchases on interest rates. Williams $(2011,2013)$ reports a summary of these findings and indicates that there is empirical evidence that these purchases have affected the longer term interest rates; however there is little evidence that these purchases have had specific effects on the macroeconomy because it is very difficult statistically to test such a hypothesis. Table 1 below presents a sample of representative studies and is reproduced from Williams (2013). There is a consensus that QEs have reduced long-term interest rates only minimally. 
ESTIMATES OF IMPACT OF ASSET PURCHASES ON 10-YEAR TREASURY YIELD

\begin{tabular}{|c|c|c|c|}
\hline Study & Sample & Method & 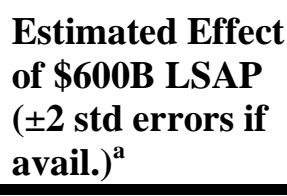 \\
\hline Greenwood-Vayanos (2008) & $\begin{array}{l}\text { post-War U.S. } \\
\text { (pre-crisis) }\end{array}$ & time series & 14 bp ( $\pm 7 \mathrm{bp})$ \\
\hline Doh $(2010)$ & QE1 & event study & $24 \mathrm{bp}$ \\
\hline Bomfim and Meyer (2010) & QE1 & event study & $18 \mathrm{BP}$ \\
\hline $\begin{array}{l}\text { Krishnamurthy-Vissing-Jorgensen (2011, } \\
\text { 2012) }\end{array}$ & $\begin{array}{l}\text { post-War U.S., } \\
\text { QE1, and QE2 }\end{array}$ & time series & $15 \mathrm{bp}( \pm 5 \mathrm{bp})$ \\
\hline Gagnon-Raskin-Remache-Sack (2011) & QE1 & $\begin{array}{l}\text { event study, time } \\
\text { series }\end{array}$ & $\begin{array}{l}30 \mathrm{bp}( \pm 15 \mathrm{bp}) \\
18 \mathrm{bp}( \pm 7 \mathrm{bp})\end{array}$ \\
\hline D'Amico and others (2011) & QE2 & event study & $45 \mathrm{bp}$ \\
\hline D’Amico-King (2013) & $\begin{array}{l}\text { QE1Treasury } \\
\text { purchases }\end{array}$ & $\begin{array}{l}\text { security-specific } \\
\text { event study }\end{array}$ & 100 bp ( \pm 80 bp $)$ \\
\hline Hamilton-Wu (2011) & U.S., 1990 -QE2 & $\begin{array}{l}\text { affine no-arbitrage } \\
\text { model }\end{array}$ & $17 \mathrm{bp}$ \\
\hline Hancock-Passmore(2011) & $\begin{array}{l}\text { QE1 MBS } \\
\text { purchases }\end{array}$ & time series & $\begin{array}{l}\text { depends, roughly } \\
30 \mathrm{bp}\end{array}$ \\
\hline Swanson (2011) & Operation Twist & event study & $15 \mathrm{bp}( \pm 10 \mathrm{bp})$ \\
\hline Joyce-Lasaosa-Stevens-Tong (2011) & U.K. LSAPs & $\begin{array}{l}\text { event study, time } \\
\text { series }\end{array}$ & $40 \mathrm{bp}$ \\
\hline Neely (2013) & $\begin{array}{l}\text { effect of U.S. } \\
\text { QE1 on foreign } \\
\text { bond yields }\end{array}$ & event study & $17 \mathrm{bp}( \pm 13 \mathrm{bp})$ \\
\hline Christensen-Rudebusch (2012) & $\begin{array}{l}\text { QE1, QE2, and } \\
\text { U.K. LSAPs }\end{array}$ & $\begin{array}{l}\text { event study, affine } \\
\text { no-arbitrage } \\
\text { model }\end{array}$ & $10 \mathrm{bp}$ \\
\hline $\begin{array}{l}\text { D'Amico-English-Lopez-Salido-Nelson } \\
\text { (2012) }\end{array}$ & $\begin{array}{l}\text { U.S., pre-crisis } \\
\text { weekly }\end{array}$ & time series & $\begin{array}{l}\text { depends, roughly } \\
45 \mathrm{bp}\end{array}$ \\
\hline Bauer-Rudebusch (2013) & QE1, QE2 & $\begin{array}{l}\text { event study, affine } \\
\text { no-arbitrage } \\
\text { model }\end{array}$ & $16 \mathrm{bp}$ \\
\hline Li-Wei (2013) & U.S., pre-crisis & $\begin{array}{l}\text { affine no-arbitrage } \\
\text { model }\end{array}$ & $26 \mathrm{bp}$ \\
\hline
\end{tabular}

Sources: Greenwood-Vayanos (2008, Table 2), Krishnamurthy-Vissing-Jorgensen (2011, Section 4), Gagnon et al. (2011, Tables 1-2), Chen and others (2012, Table 1), D’Amico-King (2013, Figure 5), Hamilton-Wu (2011, Figure 11), Hancock-Passmore (2011, Table 5), Swanson (2011, Table 3), Chung et al. (2012, Figure 10), Joyce et al. (2011, Chart 9), Neely (2013, Table 2), Bauer-Rudebusch (2013, Table 6), Christensen-Rudebusch (2012, Table 8), D'Amico et al. (2012, Conclusions), Li-Wei (2013, Tables 3, 6). a. Almost all of these estimates involve John Williams' calculations to renormalize the effect to a $\$ 600$ billion U.S. LSAP. 


\section{Data and Hypotheses}

The vast majority of papers address the impact of QE on the long-term 10-Year Treasury Note. Since QE3 has been terminated in late October 2014, there are currently no studies of its impact.

We contribute to the literature research in 3 ways. First we claim that all 3 QEs have influenced the long-term 10 year T-Note. Then we extend the influence of the $\mathrm{QE}$ to its impact on wealth as measured by the S\&P 500 Index. Even casual observation suggests that QEs have contributed substantially to increases in the total S\&P 500 index. For example, the S\&P 500 Index increased by $18 \%$ from the beginning of QE1 to its end; by $11 \%$ during the second wave of $\mathrm{QE}$ and by $26 \%$ during the third $\mathrm{QE}$. There is also evidence that the $2 \mathrm{QEs}$ have reduced the unemployment rate that stood at about $10 \%$ when the first QE was introduced and is now at the end of the third QE at 6\%. The three hypotheses to be tested can be expressed as follows:

Hypothesis \#1: Did the three rounds of QE influence the 10-year Treasury Note?

Hypothesis \#2: Did the three rounds of QE influence the S\&P 500 Index?

Hypothesis \#3: Did the three rounds of QE influence the rate of unemployment?

The data used for Quantitative easing are weekly (Wednesday) total Fed assets from December 18, 2002 to the end of QE in October 22, 2014, appropriately matched with weekly point data for the 10-year Treasury Note rate and the S\&P 500 Index. For the third hypothesis we use monthly unemployment rates and match these rates with the weekly amount of Fed assets reported immediately prior to the announcement of the unemployment rate. Our monthly data begin on Dec 25, 2002 and ends on Sept 24, 2014.

These above three hypotheses can be tested via the following regime switching regressions, assuming there are two regimes only and the regimes switch according to a Markov chain with time invariant transition probabilities.

Hypotheses 1: Weekly Data

$$
\Delta\left(\text { TenYrNote }_{\mathrm{t}}\right)=\alpha_{0, \mathrm{~S}_{\mathrm{t}}}+\alpha_{1, \mathrm{~S}_{\mathrm{t}}} \Delta\left(\mathrm{FA}_{\mathrm{t}-1}\right)+\alpha_{2, \mathrm{~S}_{\mathrm{t}}} \Delta\left(\text { TenYrNote }_{\mathrm{t}-1}\right)+\varepsilon_{1, \mathrm{~S}_{\mathrm{t}}}, \varepsilon_{1, \mathrm{~S}_{\mathrm{t}}} \square \mathrm{N}\left(0, \sigma_{1, \mathrm{~S}}^{2}\right)
$$

Hypothesis 2: Weekly Data

$$
\Delta\left(\mathrm{SP} 500_{\mathrm{t}}\right)=\beta_{0, \mathrm{~S}_{\mathrm{t}}}+\beta_{1, \mathrm{~S}_{\mathrm{t}}} \Delta\left(\mathrm{FA}_{\mathrm{t}-1}\right)+\beta_{2, \mathrm{~S}_{\mathrm{t}}} \Delta\left(\mathrm{SP} 500_{\mathrm{t}-1}\right)+\varepsilon_{2, \mathrm{~S}_{\mathrm{t}}}, \varepsilon_{2, \mathrm{~S}_{\mathrm{t}}} \square \mathrm{N}\left(0, \sigma_{2, \mathrm{~S}_{\mathrm{t}}}^{2}\right)
$$


Hypothesis 3: Monthly Data

$$
\begin{gathered}
\Delta\left(\text { UnEmploy }_{\mathrm{t}}\right)=\alpha_{0, \mathrm{~S}_{\mathrm{t}}}+\alpha_{1, \mathrm{~S}_{\mathrm{t}}} \Delta\left(\mathrm{FA}_{\mathrm{t}-1}\right)+\beta_{1} \Delta\left(\text { UnEmploy }_{\mathrm{t}-1}\right)+\beta_{2} \Delta\left(\text { UnEmploy }_{\mathrm{t}-2}\right)+\varepsilon_{1, \mathrm{~S}_{\mathrm{t}}} \\
\varepsilon_{1, \mathrm{~S}_{\mathrm{t}}} \square \mathrm{N}\left(0, \sigma_{1, \mathrm{~S}}^{2}\right)
\end{gathered}
$$

Following Hamilton (1994), the matrix of transition probabilities is defined as:

$$
P=\left(\begin{array}{ll}
P_{11} & P_{12} \\
P_{21} & P_{22}
\end{array}\right) \text {, with } \sum_{\mathrm{s}=1}^{2} \mathrm{P}_{\mathrm{sj}}=1, \text { and } \mathrm{P}_{\mathrm{sj}} \geq 0 \text { for } \mathrm{s}, \mathrm{j}=1,2 .
$$

The expected duration of the high volatility regime is given by $E(S=1)=1 /\left(1-P_{11}\right)$ and that for the low volatility regime is given by $\mathrm{E}(\mathrm{S}=2)=1 /\left(1-\mathrm{P}_{22}\right)$.

It is important to point out before proceeding with the analyses of the results that all data series are first differenced to avoid non-stationarity issues. Thus, for SP500 we use log of the changes.

\section{Analysis of Results}

Our results are presented in Tables 1, 1a, 2, 2a, 3, 3a and others that follow.

In our analysis with three different target variables i.e. Ten Year Note, the S\&P 500 index and the unemployment rate, the effect of Fed Asset changes have differing impacts in the two different regimes.

We allow regime structures to address changes in unconditional (historical) volatility over the sample period. An economist does not observe the regimes, but has to infer that from the data. The estimation routine generates two interesting by-products in the form of regime probability and the smooth probability. Kim and Nelson (1999) discuss these algorithms in great depth in chapter 4 . The regime probability at time $t$ is the probability that a particular state is operating at that time, conditional on all information up to (t-1). This is a key input for forecasting purposes. The other by-product is the smooth probability, which is the probability of a particular state in operation at $t$ conditional on all information in the sample. In some sense, the smooth probability allows the researcher to 'look back' and observe how regimes have evolved over time. In the following paragraph we focus on this topic.

With visual inspection of the plot of the probability of staying in the low volatility regime, it appears that, as if, there has been a change of behavior around January 2008. The 
sample has been classified in two different levels of volatility. The volatility measures for two regimes are statistically significant as well as the elements of the transition probability matrix. The probability of staying in the low volatility regime is higher and it is apparent from both the tables.

From Table 1 it is clear that the Fed Asset changes have no impact on Ten Year Note in either regime. From Table 1a we see that there are a low volatility regime lasting on average 88.6 weeks and a high volatility regime lasting 36.7 weeks. In general the volatility of the 10-Year Note was not turbulent during the pre-crisis or the post crisis period and our methodology does not confirm a significant impact of QE on the Ten Tear Note. This is consistent with most other studies.

Table 2 shows that the low and high volatility regimes are shorter than the ones of the Ten Year Note. From Table 2a we see that the low volatility regime lasts 14.1 weeks and the high volatility only 7.6. Table 1 indicates that Fed Asset changes influence negatively the S\&P 500 in the high volatility level. This makes sense because equity markets appeared to correct whenever there were expectations of discontinuing QE.

Finally, Table 3 indicates that unemployment was influenced by QE only in the low volatility regime. Table $3 \mathrm{a}$ illustrates that the unemployment was very turbulent during the crisis. 


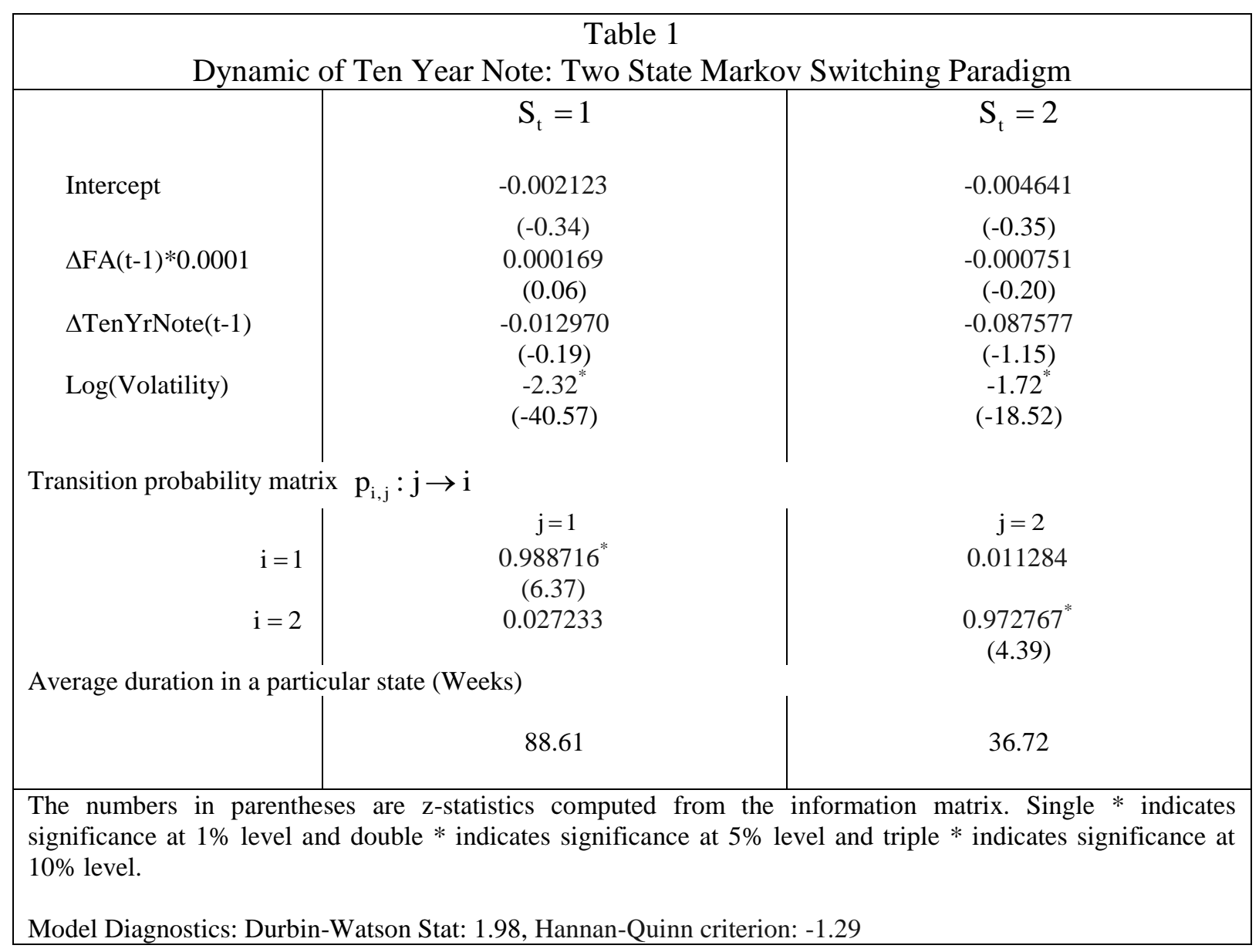

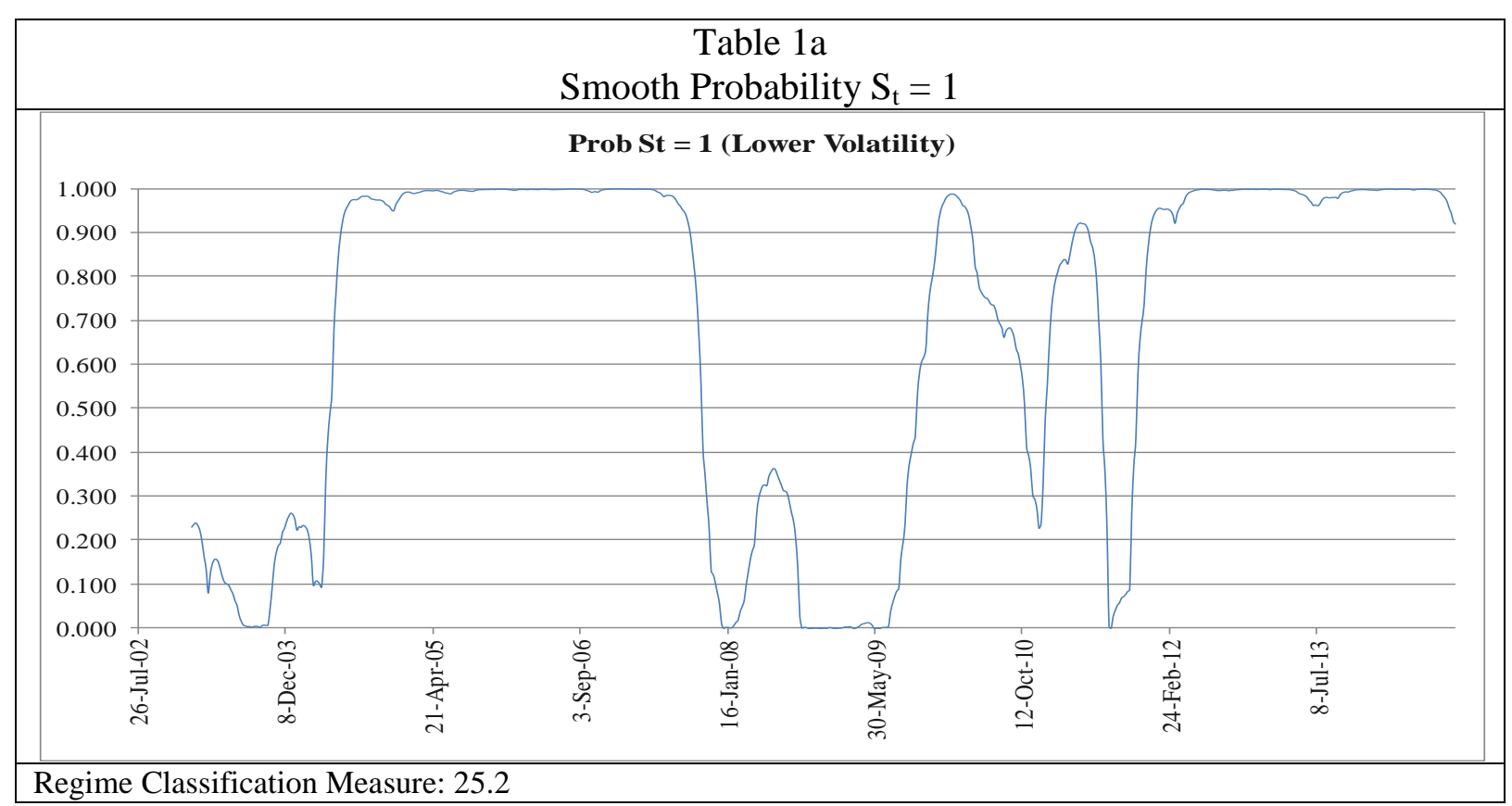




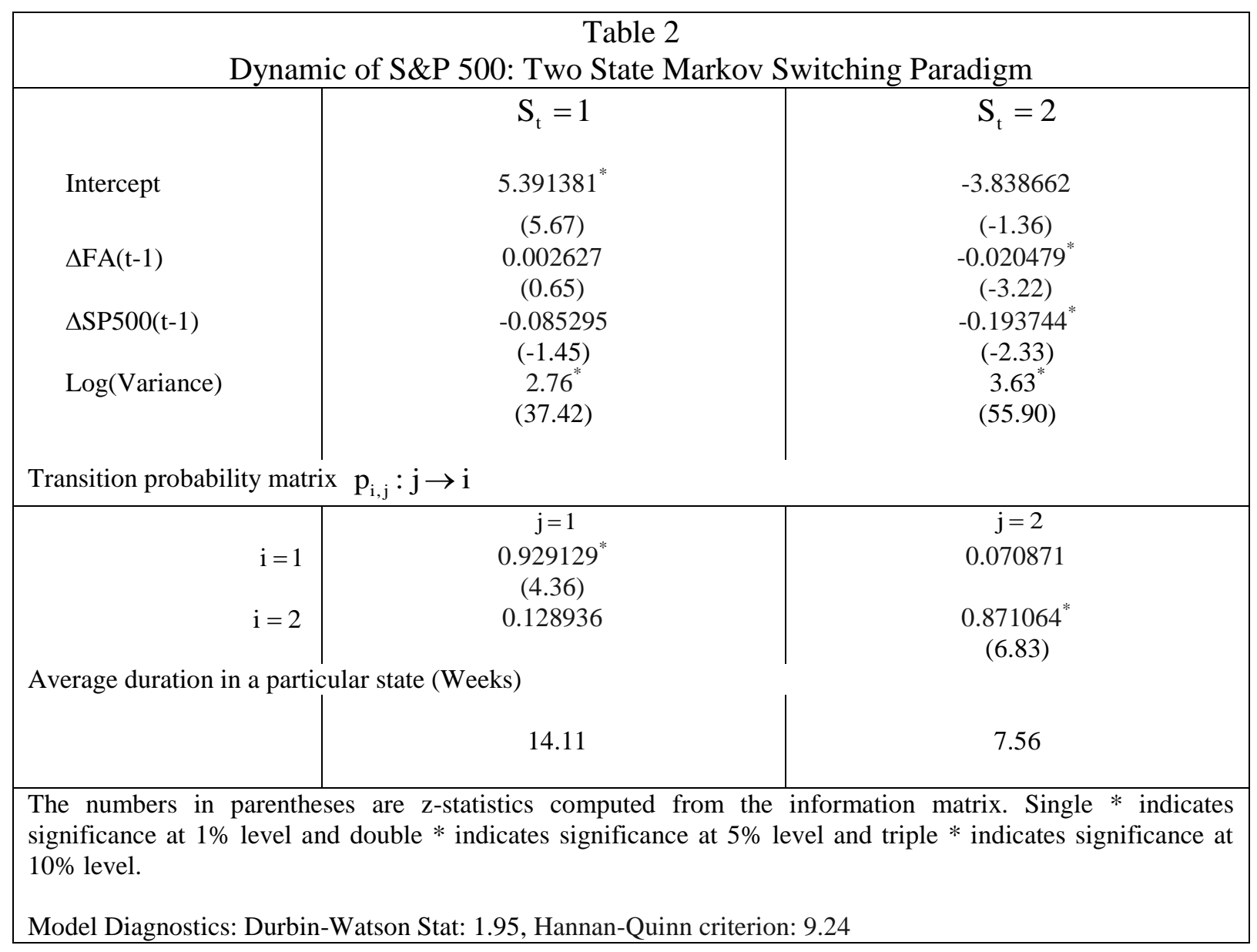

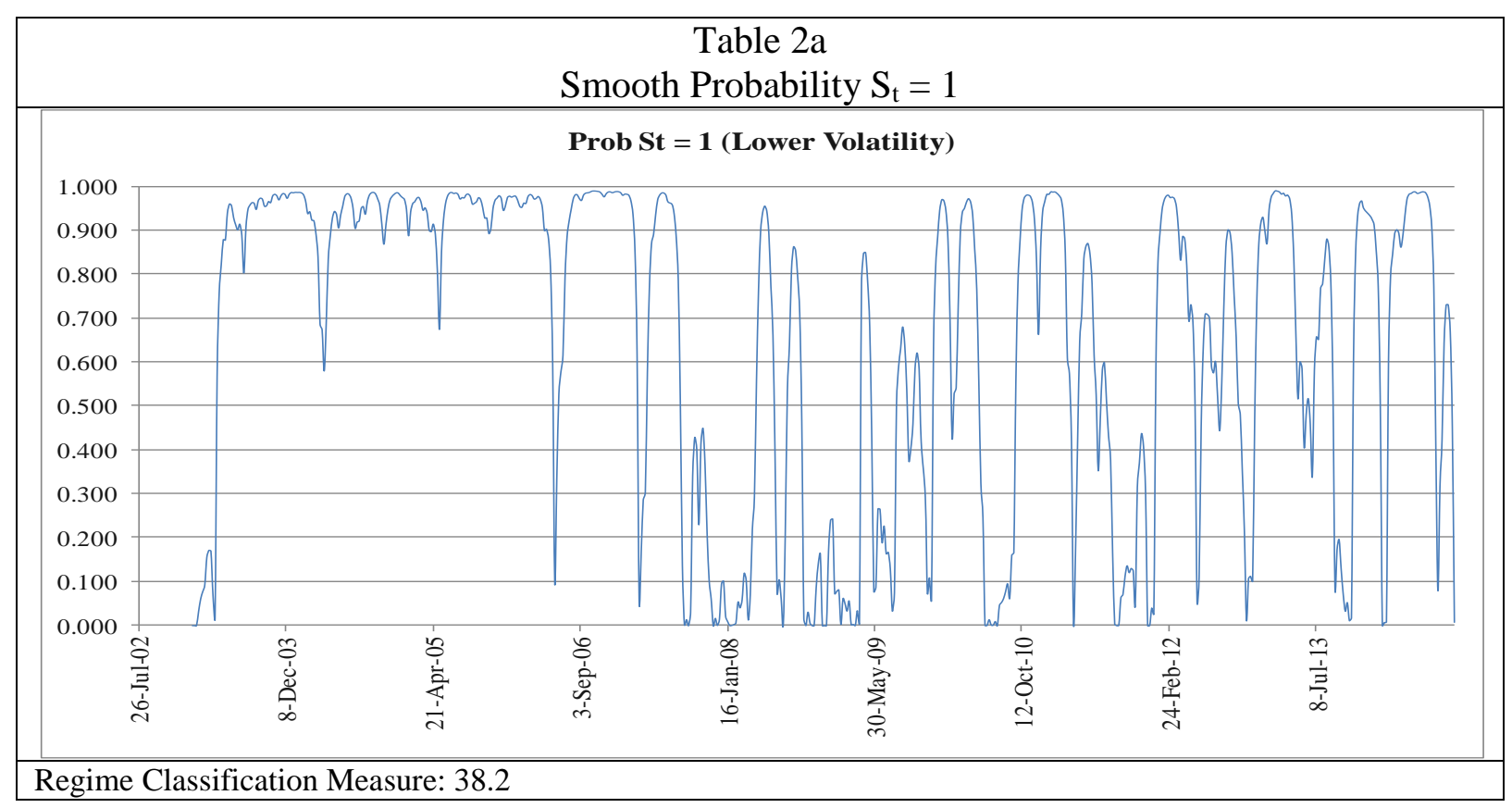




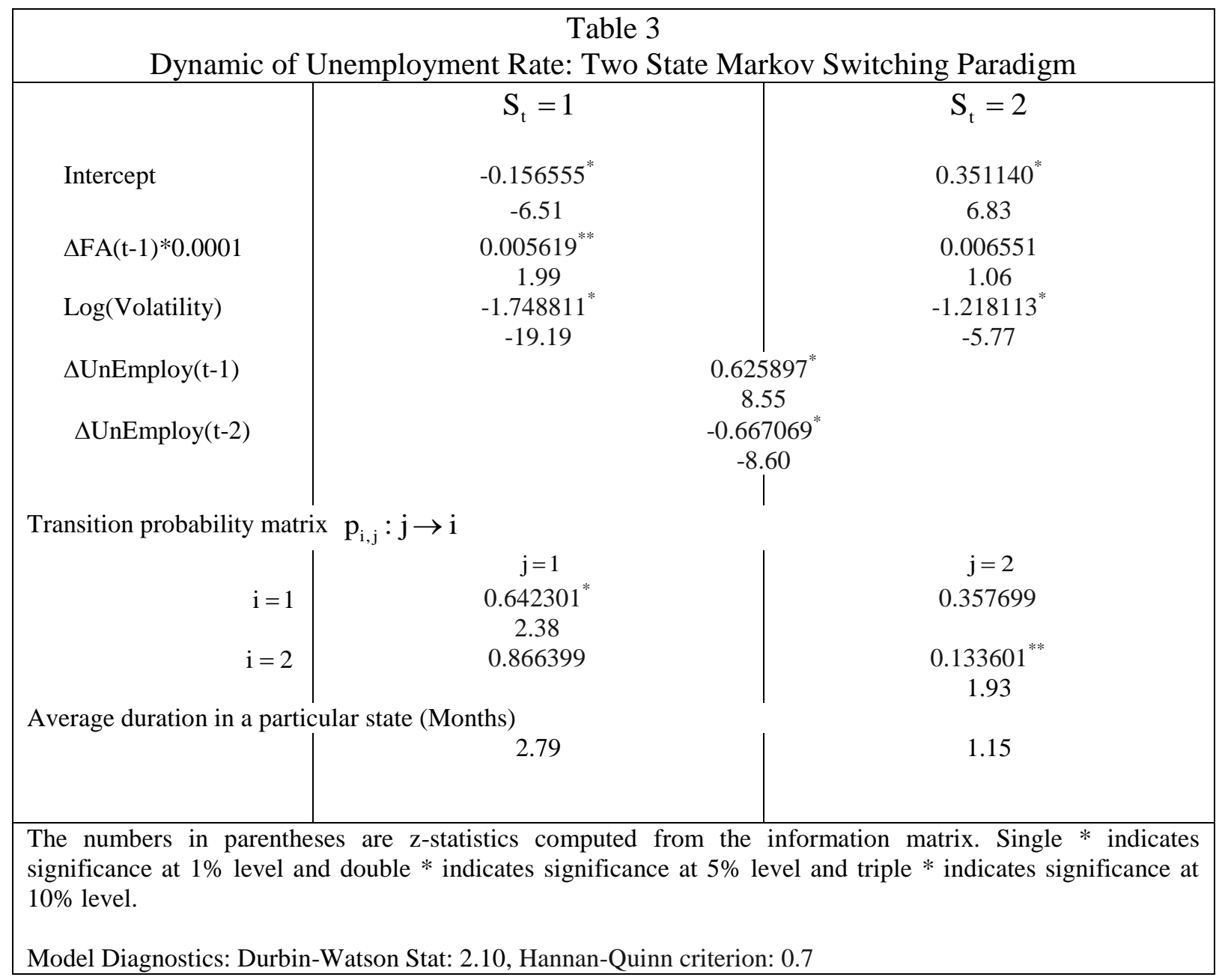

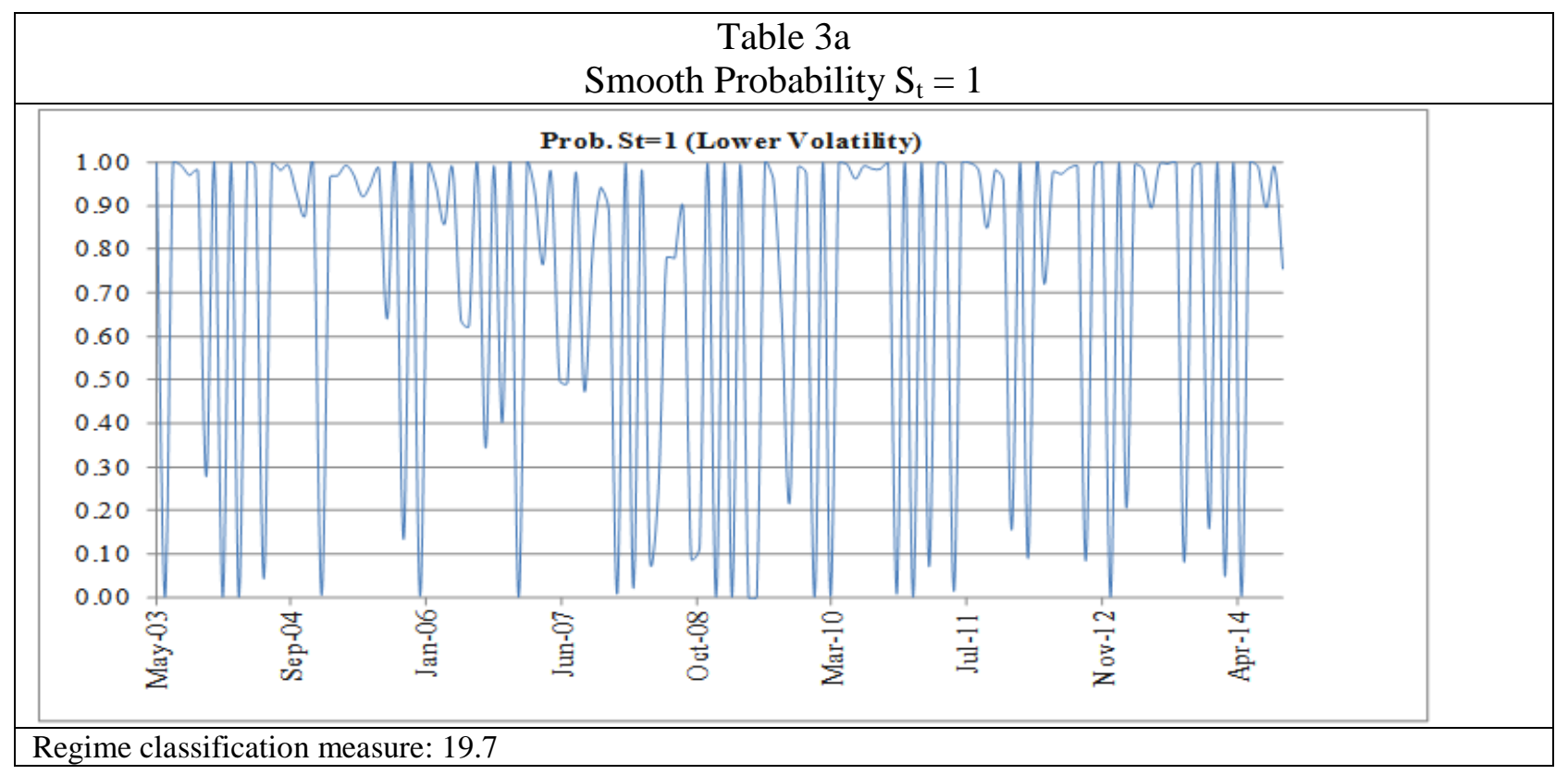




\section{Model Diagnostics}

After estimating and discussing the results of the Markov-switching models above, it is important to check for model adequacy. In this framework, it is a common practice to assess the adequacy of these fitted models in at least the following two dimensions. The first is the BDS (explained below) test which checks for the independence of the residuals, and the second is the RCM (Regime Classification Measure) test which analyzes the generated regime probability series in order to infer on the fitted models' ability to recognize regimes from the behavior of the data at any point of time. These tests are explained below.

\section{Residual Diagnostics:}

It is a common practice for assessing adequacy of Markov switching models to apply the test of independence to the residual series (see Pagan and Hall, 1983). A powerful test used for independence and, under certain circumstances, for nonlinear dependencies, was developed by Brock et al. (1996) and is based on the correlation integral. The BDS statistic tests the null hypothesis that the elements of a time series are independently and identically distributed (IID). For a time series which is IID, the distribution of the statistic is asymptotically standard normal under the null of white noise. The null is rejected if the test statistic is absolutely large, (say greater than 1.96). If the null hypothesis of IID is rejected, this implies that the residuals contain some kind of dependence i.e. linear or non-linear. We have carried out the BDS test for the model residuals in E-views and the results are tabulated in Table 4. The test requires choice of two parameters, commonly referred to as the dimension and epsilon, the distance for testing proximity of the data points. In all our tests we used epsilon as a fraction of the range of the residual data series. In the BDS test, under the assumption of IID, the probability of the distance between any pair of points is less than or equal to the epsilon will be constant. Thus using epsilon as a fraction of the range is meaningful for a residual series (Brook et al. (1996)).

The BDS test statistics in Table 4 show that the hypothesis of IID nature of the residual series is well supported except for all the dimensions used in the study. We, thus, find statistical support for the Markov-switching models in this regard. This adds to the incapability of any linear model to address either the parameter instability and/or variance instability over the sample period. Table 4 thus supports that all the three models (Ten Year Note and S\&P 500 as 
targets) as well as the unemployment rate in the regime switching framework. The residuals are being accepted as IID.

\begin{tabular}{|c|c|c|c|}
\hline \multicolumn{4}{|c|}{ Table 4 } \\
\hline Dimension & Ten Year Note (Model) & S\&P 500 (Model) & Unemployment (Model) \\
\hline 2 & -0.002063 & 0.001223 & -0.001289 \\
\hline 3 & -0.005506 & 0.002105 & 0.002376 \\
\hline 4 & -0.004043 & 0.007853 & 0.003701 \\
\hline 5 & -0.002422 & 0.008742 & -0.002654 \\
\hline 6 & -0.000600 & 0.009871 & -0.007871 \\
\hline $\begin{array}{l}\text { Notes: BDS test refers to the test developed by Brock, Dechert, Scheinkman and Labaron (1996) to assess adequacy } \\
\text { of Markov switching models. }\end{array}$ \\
\hline
\end{tabular}

\section{Residual Heteroscedasticity:}

Another dimension of model appropriateness is obtained from examining the heteroscedasticity in the model residuals. In Table 5 we provide the results for any remaining ARCH effects in the residuals series. It clearly demonstrates that our model with regime-dependent unconditional variances adequately addresses this issue. The empirical researchers usually address residual heteroscedasticity using GARCH type specification. In this model, we address the heteroscedasticity in the data in the same way as in Fong and See (2002) by allowing the residual variance to be state dependent. In this Markov-switching model, the unconditional variance is allowed to switch, whereas in the GARCH model the conditional variance changes but the unconditional variance however remains fixed. In such regime-based models, it is customary to let residual variances define the regimes - low and high variance regimes.

\begin{tabular}{lc}
\hline \multicolumn{2}{c}{ Table 5 } \\
\multicolumn{2}{c}{ Residual Heteroscedasticity Test } \\
\hline Ten Year Note (Model) & 0.036 \\
S\&P 500 (Model) & 0.013 \\
Unemployment (Model) & 0.969 \\
\hline The entries are p-values for Ljuang-Box tests of order 24 using \\
squared residuals. The hypothesis of remaining ARCH effect may be \\
rejected for p-value greater than 0.05 (0.01) at the 5\% (1\%) level of \\
significance. \\
For unemployment monthly data this statistic is computed at lag 12. \\
\hline
\end{tabular}




\section{$\underline{\text { Regime Classification Measure }}$}

A source of uncertainty idiosyncratic to regime switching models is the ex-post determination of regimes. In switching models, it is assumed that the occurrence of a regime is observed by the market but not by the econometrician who must infer it from the model. Until recently, the quality of regime classification was determined by focusing on the smoothed ex-post regime transition probabilities. An innovation in this area is the Regime Classification Measure (RCM) proposed by Ang and Bekaert (2002). This is essentially a sample estimate of the variance of the probability series. It is based on the idea that perfect classification of regime would infer a value of 0 or 1 for the probability series and would be a Bernoulli random variable. The Regime Classification Measure (RCM) is defined as:

$$
400 \times \frac{1}{\mathrm{~T}} \times \sum \mathrm{p}_{\mathrm{t}} \times\left(1-\mathrm{p}_{\mathrm{t}}\right)
$$

where $p_{t}$ is the probability of being in a certain regime at time $t$. Good regime classification is associated with low RCM statistic values. A value of 0 means perfect regime classification and a value of 100 implies that no information about the regimes is revealed. Weak regime inference implies that the model cannot successfully distinguish between regimes from the behavior of the data and may indicate misspecification.

With the data for the probability series for the three models in our study, the RCM measures are tabulated in Tables 1a, 2a and 3a. We can see that the RCM values for all the series are reasonably low, especially when compared to those reported in Ang and Bekaert (2002). This shows that the model with two regimes is able to confidently distinguish which regimes are occurring at each point in time. The lowest value for RCM is for the model with unemployment rate as the target variable indicating erratic behavior of this data in relation to the asset purchase program. The other two values are close enough to be conveying any other significant information.

The low RCM measures for the data sets indicate reasonable performance of the switching regime model with respect to the quantitative easing episodes. 


\section{Conclusions}

This paper reviews the large purchases of bonds and mortgage backed securities by the Federal Reserve Bank during the past 5 years. During these three programs known as Quantitative Easing, the Fed attempted to reduce long-term interest rates and encourage investment spending. Numerous studies reported in this paper and elsewhere document that these three rounds of QE had a minimal impact on long-term interest rates for an average of about 20-30 basis points.

In this paper we revisit the investigation of the impact of QE on long-term interest rates and confirm the earlier results; we show that QE did not impact the Ten Year Note rate. We also go beyond earlier studies and investigate the impact of QE on equities as measured by the S\&P 500 Index and also on unemployment. Our results confirm that the impact of QE on equities has been significant only in the high volatility regime. We conclude that the Fed's channel of quantitative easing that originally targeted the lowering of long-term interest rates was less successful than the targeting of equities that turned out to be more successful. Thus QE succeeded more in increasing wealth and thus consumption rather than lowering interest rates and increasing investments. Finally, we also confirm that QE impacted unemployment only in the low volatility regime.

The overall conclusion of this study is that much more work is needed to fully understand how QE has impacted the US economy and to confirm the econometric evidence. 


\section{References}

Ang, A., \& Bekaert, G. (2002), Regime switches in interest rates, Journal of Business and Economic Statistics 20, 163-182.

Bauer, Michael, and Glenn Rudebusch. 2013. "The Signaling Channel for Federal Reserve Bond Purchases.” International Journal of Central Banking, forthcoming.

Brock, W. A., Dechert, W. D., Scheinkman, J. A., \& LeBaron. B. (1996), A test for independence based on the correlation integral, Econometric Reviews 15, 197-235.

Chen, Han, Vasco Cúrdia, and Andrea Ferrero. 2012. "The Macroeconomic Effects of Large Scale Asset Purchase Programmes.” The Economic Journal 122(564), pp. F289-F315.

Christensen, Jens, and Glenn Rudebusch. 2012. "The Response of Interest Rates to US and UK Quantitative Easing.” Economic Journal, 122, pp. F385-F414.

Chung, Hess, Jean-Philippe Laforte, David Reifschneider, and John Williams. 2012. "Have We Underestimated the Likelihood and Severity of Zero Lower Bound Events?" Journal of Money, Credit and Banking, 44, pp. 47-82.

Doh, Taeyoung. 2010. "The Efficacy of Large-Scale Asset Purchases at the Zero Lower Bound," Federal Reserve Bank of Kansas City, Economic Review, Second Quarter.

D'Amico, Stefania, and Thomas B. King. 2010. "Flow and Stock Effects of Large- Scale Treasury Purchases," Federal Reserve Board, Finance and Economics Discussion Series.

D’Amico, Stefania, William English, David Lopez-Salido, and Edward Nelson. 2012. "The Federal Reserve's Large-Scale Asset Purchase Programs: Rationale and Effects,” Federal Reserve Board, working paper.

Fong, W. M., \& See, K. H. (2002), A Markov switching model of the conditional volatility of crude oil futures prices, Energy Economics 24, 71-95.

Gagnon, Joseph, Matthew Raskin, Julie Remache, and Brian Sack. 2011. International Journal of Central Banking 7, pp. 3-43.

Greenwood, Robin, and Dimitri Vayanos. 2008. "Bond Supply and Excess Bond Returns." NBER Working Paper 13806.

Hamilton, James, and Jing Cynthia Wu. 2012. "The Effectiveness of Alternative Monetary Policy Tools in a Zero Lower Bound Environment." Journal of Money, Credit, and Banking 44, pp. 3-46.

Hamilton J. D. (1994), Time Series Analysis. Princeton: Princeton University Press. 
Hancock, Diana, and Wayne Passmore. 2011. "Did the Federal Reserve's MBS Purchase Program Lower Mortgage Rates?” Journal of Monetary Economics 58(5), pp. 498-514.

Joyce, Michael, Ana Lasaosa, Ibrahim Stevens, and Matthew Tong. 2011. "The Financial Market Impact of Quantitative Easing." International Journal of Central Banking 7(3), pp. 113161. http://www.ijcb.org/journal/ijcb11q3a5.htm

Kim, C. J., \& Nelson, C. R. (1999), State space models with regime switching, classical and Gibbs sampling approach with application, Cambridge, MA: The MIT Press.

Krishnamurthy, Arvind, and Annette Vissing-Jorgensen. 2011. "The Effects of Quantitative Easing on Interest Rates.” Brookings Papers on Economic Activity 43(2), pp. 215-287.

Li, Canlin, and Min Wei. 2013. "Term Structure Modeling with Supply Factors and the Federal Reserve's Large-Scale Asset Purchase Programs.” International Journal of Central Banking 9(1), pp. 3-39.

Neely, Christopher. 2013. "Unconventional Monetary Policy Had Large International Effects." Federal Reserve Bank of St. Louis Working Paper 2010-018D. http://research.stlouisfed.org/wp/2010/2010-018.pdf

Pagan, A. R., \& Hall, A. D. (1983), Econometric Reviews 2, 1983, 159-218.

Swanson, Eric. 2011. "Let's Twist Again: A High-Frequency Event-Study Analysis of Operation Twist and Its Implications for QE2.” Brookings Papers on Economic Activity 42(1), pp. 151-207.

Williams, John C. 2011. "Unconventional Monetary Policy: Lessons from the Past Three Years." FRBSF Economic Letter 2011-31 (October 3).

Williams, John C. 2013, "Lessons from the Financial Crisis for Unconventional Monetary Policy", Panel Discussion at the NBER Conference, October 18, 2013.

Woodford, Michael. 2012. "Methods of Policy Accommodation at the Interest-Rate Lower Bound," The Changing Policy Landscape, Jackson Hole Economic Symposium, Federal Reserve Bank of Kansas City, August 30-September 1. 